\section{Is New Ibovespa The Best Investment Option?}

\author{
Ricardo Goulart Serra 12 \\ ${ }^{1}$ Foundation School of Commerce Alvares Penteado, Sao Paulo, SP, Brazil \\ ${ }^{2}$ Insper Institute of Education and Research, Sao Paulo, SP, Brazil \\ Wilson Toshiro Nakamura \\ Mackenzie Presbyterian University, Graduate Studies \\ Program in Business Administration, Sao Paulo, SP, Brazil
}

Received on

Juno/06/2015

Approved on

Jan/05/2016

Responsible editor:

André Taue Saito

Evaluation process:

Double Blind Review

\begin{abstract}
Purpose - Verify whether Ibovespa, Old or New, could be the best alternative for investors, considering investment possibilities (risky and risk free) in the Brazilian market. Should investors put the portion of money that they allocate to risky assets into New Ibovespa? Are there more efficient alternatives for investors?
\end{abstract}

Design/methodology/approach - The Portfolio $T$ was determined with the modern portfolio theory from a sample of 118 shares for 34 four-month periods. Equality of means and variance were tested by means of parametric and nonparametric tests, as appropriate.

Findings - Studying New Ibovespa (calculated retroactively) in the period between January 1, 2003 and April 30, 2014, it was concluded that, (i) analyzing the entire period, (a) New Ibovespa was dominated by a portfolio obtained by applying the concepts of the modern portfolio theory (portfolio T), and (b) New Ibovespa dominated Old Ibovespa, and (ii) analyzing each of the 34 four-month periods individually, New Ibovespa was dominated by the portfolio $T$ in 13 out of the 18 four-month periods in which there had been statistically significant dominance $(72,2 \%$ of all cases).

Originality/value - The paper contributes to the study of the New Ibovespa, offering 118 shares to determine the Portfolio $\mathrm{T}$ and for a 34 four-month period. To the best knowledge of the authors, no other paper studied the New Ibovespa. It can be concluded that, for the period analyzed, when compared to New Ibovespa, the portfolio $T$ would have been a better investment alternative.

Keywords - Ibovespa; Portfolio Theory; Sharpe Ratio.

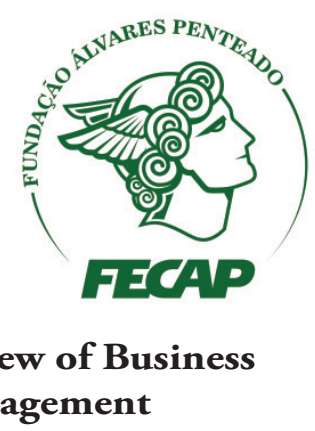

DOI: $10.7819 /$ rbgn.v18i59.2541 


\section{Introduction}

Markowitz (1952) proposes that, when choosing risky assets, one must analyze the risk alongside the return; risk is undesirable and return is desirable. The author shows that, among the many available possibilities of portfolios formed by risky assets, there is a set of efficient portfolios (portfolios that would not be dominated by others). According to him, "the investor, being informed of what (return, risk) combinations were attainable, could state which he desired" (Markowitz, 1952, p. 82) to then be presented with the risky assets' portfolio which would produce the chosen combination.

In the transcript above, one can observe that the choice between the various possibilities of efficient portfolios would be specific to each investor, since investors have different risk aversion levels and should make their own choices.

Tobin (1958), introducing the risk free asset among investors' possible choices, proposes a single portfolio solution (portfolio $\mathrm{T}$ ) for all investors. This portfolio, combined with the risk free asset, would produce portfolios that dominate the set of efficient portfolios proposed by Markowitz (1952), except for the portfolio T itself (present in both solutions, Markowitz and Tobin). Thus, regardless of investors' degree of risk aversion, "no investor will choose to invest in any other risky portfolio except portfolio $T$ " (Copeland, Weston, \& Shastri, 2005, p. 133) if they believed they knew the efficient frontier and could buy and sell risk free assets (Elton, Gruber, Brown, \& Goetzmann, 2004, p. 92).

The portfolio $\mathrm{T}$ offers a determined level of risk; thus, for the risk level to be appropriate to the risk aversion profile of several investors, the resources of each investor are divided between the portfolio $T$ and the risk free asset at a ratio that results in a risk level that is appropriate to the profile of each respective investor. Market indexes are usually considered a proxy to the portfolio $\mathrm{T}$. The most widely used market index in Brazil is the Bovespa index (Ibovespa). The Ibovespa portfolio is made up of assets that meet the inclusion criteria established by BM\&FBovespa methodology. At the end of 2013, changes were announced in the inclusion criteria and they were implemented in stages from 2014 on. The Ibovespa portfolio that meets the old criteria will be referred to as Old Ibovespa, and the Ibovespa portfolio that meets the new criteria will be referred to as New Ibovespa.

The goal of this paper is to verify whether Ibovespa, Old or New, could be the best alternative for investors, considering investment possibilities (risky and risk free) in the Brazilian market. Could Ibovespa be the portfolio T, or is there another portfolio that, combined with risk free asset, would be able to produce more efficient alternatives for investors than Ibovespa combined with risk free asset? Is New Ibovespa a better alternative compared to Old Ibovespa? In this sense, the research hypotheses of this paper are:

HI: portfolio $T$, formed according to the precepts of modern portfolio theory, is superior to New Ibovespa, in terms of return and variance.

HII: portfolio $\mathrm{T}$, formed according to the precepts of modern portfolio theory, is superior to Old Ibovespa, in terms of return and variance.

HIII: New Ibovespa is superior to Old Ibovespa, in terms of return and variance.

The analysis period goes from January 1, 2003, to April 30, 2014, and is made up of 34 four-month periods. This paper analyzed (i) Old Ibovespa, (ii) New Ibovespa, recalculated "pro forma" retroactively, to reflect criteria changes recently promoted for the formation of the Ibovespa portfolio, and (iii) a portfolio $\mathrm{T}$ calculated according to modern portfolio theory.

As well as this introductory section, this paper contains the following sections: theoretical framework, methodology, data analysis and final considerations. 


\section{Theoretical Framework}

\section{I The modern portfolio theory}

Finance aims to help firms and/or individuals in their financing and investment decisions. With regard to investment decisions, especially in uncertain environments, it intends to help investors identify into which asset or set of assets (technically, a portfolio is also considered an asset) investors should allocate their resources.

There are a few approaches to dealing with this investment decision; the most recurrent, due to its theoretical and empirical contents and applicable analytical framework, is the one that considers the mean-variance binomial as object of choice. An alternative framework is the well-known state preference framework, which, although broader, is harder to implement and empirically validate, since it is almost impossible to list all the potential payoffs in all possible states of nature (Copeland et al., 2005, p. 101).

The mean-variance framework began with Markowitz (1952), who raised risk to the same level of importance that was until then given exclusively to returns, regarding decision-making. According to Copeland et al. (2005), quantifying risk was one of the most important advances in finance theory.

The mean and variance of the historical distribution of the returns from a particular asset are conveniently used to characterize the return and the risk, respectively, of such asset. Moreover, so that only the mean and variance describe a distribution of returns, it is necessary to assume that this distribution of returns is parametric, for example, the normal distribution.

Based on a set of individual assets it is possible, by varying the weight of each asset in the portfolio, to put together a large number of portfolios. To calculate the mean and variance for portfolios one uses Equations 1 - mean - and 2 - variance (Markowitz, 1952):

$$
E\left(r_{c}\right)=\sum_{i=1}^{N} p_{i} \times E\left(r_{i}\right)
$$

In which,

$E\left(r_{c}\right)=$ expected portfolio's return

$\mathrm{N}=$ number of assets in portfolio

$\mathrm{w}_{\mathrm{i}}=$ weight of asset $\mathrm{i}$ in portfolio

$\mathrm{E}\left(\mathrm{r}_{\mathrm{i}}\right)=$ expected return of asset $\mathrm{i}$

$$
\operatorname{var}_{c}=\sum_{i=1}^{N} \sum_{j=1}^{N} p_{i} \times p_{j} \times \operatorname{correl}_{i j} \times d p_{i} \times d p_{j} \quad \text { Eq. } 2
$$

In which,

$\operatorname{var}_{c}=$ portfolio's variance

$\mathrm{N}=$ number of assets in portfolio

$w_{i}$ and $w_{i}=$ weight of asset $i$ and of asset $j$ in portfolio

$d p_{i}$ and $d p_{j}=$ standard deviation of asset $i$ and of asset $j$

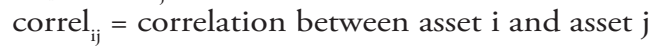

It is known that, with a set of risky assets, one can obtain portfolios that fill up a solid, flat and hyperbolic space (Merton, 1972, p. 1856), in a graphic of risk (measured by standard deviation) and return, as shown in Figure 1.

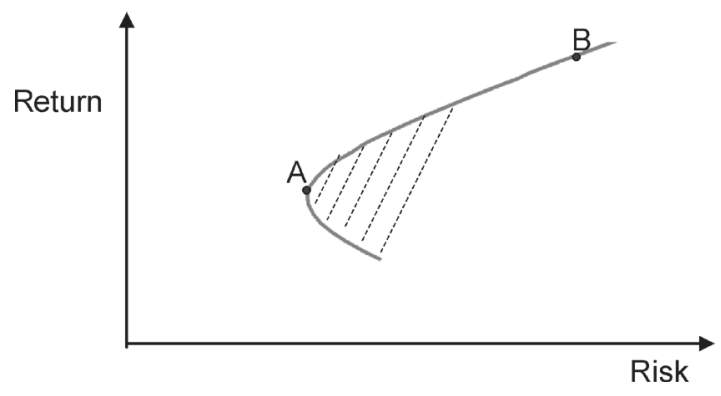

Figure 1. Portfolios formed from a set of risky assets

Considering that investors prefer more wealth to less wealth, and that they do not like risk (are risk averse) - both proposals on which various finance frameworks are based -, on can verify that various portfolio possibilities are dominated by better possibilities. One can think about dominance based on (i) risk (smaller risk for same return), (ii) return (greater return for same risk) or (iii) both (smaller risk and greater return). Thus, in Figure 1, it can be observed that the portfolios in segment $\mathrm{AB}$ (and beyond $\mathrm{B}$ ) are not dominated and, therefore, form the so-called efficient investment frontier.

Since investors - some more risk averse than others - have different preferences (represented by 
a personal utility curve), the portfolio an investor chooses from the components of the efficient investment frontier is a matter to be resolved in the context of each individual investor. Investors with greater risk aversion prefer portfolios that are closer to the portfolio represented at point $\mathrm{A}$, and investors with smaller risk aversion prefer portfolios closer to the one represented at point $B$ (or beyond).

However, investors can buy a risk free asset $\left(r_{f}\right)$ as well as a set of risky assets (risky portfolio). In this case, portfolio possibilities (now with the risk free asset) expand to those shown in Figure 2 (Tobin, 1958). In this figure, it can be observed that the portfolios made up only of risky assets from segment $A B$ in Figure 1 (the efficient investment frontier) are dominated by portfolios also made up of the risk free asset from line CD, called the capital market line (or CML).

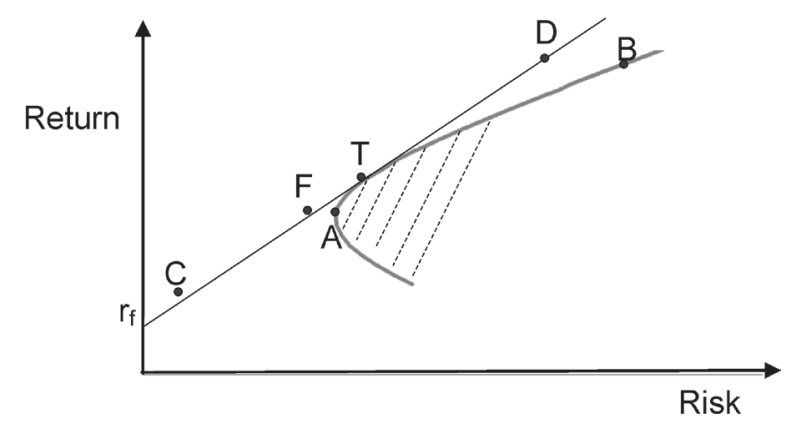

Figure 2. Capital Market Line (line CD)

It can be seen, therefore, that the best risky asset portfolio for investors would be the portfolio $\mathrm{T}$ - the one that just touches the $\mathrm{AB}$ segment, regardless of investors' risk aversion. Adequacy to the risk aversion of each individual investor would occur by allocating his money between risk free assets and the portfolio T. Investors with greater risk aversion prefer portfolios that are closer to the portfolio represented at point $\mathrm{C}$ (with greater allocation of their investments in the risk free asset $-r_{f}$ ); investors with smaller risk aversion prefer portfolios that are closer to the portfolios represented at point $\mathrm{F}$ (with greater allocation of their investments in the portfolio T); and investors with a great appetite for risk can leverage their investments in the portfolio $\mathrm{T}$, approaching the portfolio represented in point $\mathrm{D}$.

Please note that, if an investor chooses any other risky asset portfolio rather than the portfolio $T$, investment opportunities (according to the allocation between a risk free asset and a risky portfolio) would be comparatively worse than those obtained through the portfolio $T$, and the line including these possibilities would be less sloped than line CD (see Figure 3).

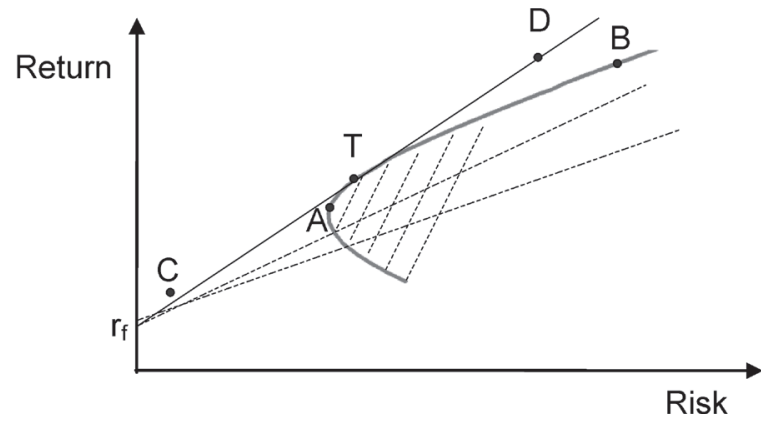

Figure 3. Portfolio possibilities with the Risk Free Asset

Thus, the best portfolio for an investor would be the one with the greatest slope, measured according to Equation 3.

$$
\mathrm{b}=\frac{\Delta \mathrm{y}}{\Delta \mathrm{x}}
$$

In which,

$\mathrm{b}=$ slope

$\Delta y=$ variation of $y$

$\Delta \mathrm{x}=$ variation of $\mathrm{x}$

Using a portfolio $\mathrm{C}$, with risk $\mathrm{dp}_{\mathrm{c}}$ and a return $r_{c}$, and risk free asset with return $r_{f}$ and $d p$ zero, one has Equation 4.

$$
\mathrm{b}=\mathrm{IS}=\frac{\mathrm{r}_{\mathrm{c}}-\mathrm{r}_{\mathrm{f}}}{\mathrm{dp} \mathrm{p}_{\mathrm{c}}} \quad \text { Eq. } 4
$$

In which,

$\mathrm{b}=$ slope

$r_{c}=$ portfolio's return

$r_{\mathrm{f}}=$ risk free asset return (risk free rate)

$\mathrm{dp}_{\mathrm{c}}=$ portfolio's standard deviation 
This same slope is known as the Sharpe Ratio or IS (Sharpe, 1966).

In this context, one can conclude that a portfolio with a higher Sharpe Ratio $\left(\mathrm{C}_{\mathrm{IS}+}\right)$ is better than a portfolio with a smaller Sharpe Ratio $\left(\mathrm{C}_{\mathrm{IS}-}\right)$, since the former $\left(\mathrm{C}_{\mathrm{IS}+}\right)$ combined with the risk free asset would result in alternatives that would dominate the alternatives obtained from the second $\left(\mathrm{C}_{\mathrm{IS}-}\right)$ and the risk free asset.

There are several other portfolio performance measures, but the one used in this paper is the Sharpe Ratio, because the proposed portfolios were based on the establishment of the portfolio $T$ - the latter being essentially the portfolio with the greatest IS, made up of risky assets.

\subsection{Ibovespa}

Ibovespa is the São Paulo Stock Exchange's (BM\&FBovespa) main index. Its goal is to be "the average performance index of the prices of the most traded and representative stocks in the Brazilian stock market” (BM\&FBovespa, 2014a).

Ibovespa has always been criticized for the high concentration of certain shares in its composition, because its composition criteria is strongly based on liquidity and for having different criteria for maintaining and including shares (for example, Rabelo, 2007; Sheng \& Saito, 2002; Takamatsu \& Lamounier, 2006).

On September 11, 2014, BM\&FBovespa announced Ibovespa's new methodology. This change took place partially in January 2014, and fully, in May 2014.

The changes impact the rules (i) for inclusion in the index (increase in the negotiability index, change in the criteria for participating in trading sessions, and not being "penny stock" or being listed as a "special situation"); and (ii) the definition of weight of each share in the index (which gives greater importance to the total traded value and establishes a participation limit).

It is not the purpose of this paper to assess whether the changes made to Ibovespa solve the criticism addressed to it.

\subsection{A brief review of the literature on portfolio optimization}

Nothing guarantees that market indexes (for example, Ibovespa) are efficient portfolios (Thomé, Leal \& Almeida, 2011). Several authors have dedicated themselves to checking whether portfolios that are optimized by certain rules (for example, the modern portfolio theory) are capable of being superior to market indexes. Moreover, according to common sense, market indexes are often far from the efficient investment frontier (Levy \& Roll, 2010).

Hieda and Oda (1998) studied twelve four-month periods between 1994 and 1998. They set up three investment strategies: (1) Ibovespa (Old), (2) portfolio $\mathrm{T}$ (considering $\mathrm{CDI}$ as the risk free asset and offering the 20 most traded shares to make up this portfolio, using quarterly parameters) and (3) the portfolio that they called the naïve strategy (with the same weight for each of the 20 most liquid shares). The analyzed portfolio $T$ only reached a higher Sharpe Ratio in one of the twelve four-month periods.

Bruni and Fama (1998) analyzed the effects of diversification, in the period between July 1993 and June 1998, with the 20 most liquid stocks. The authors studied (1) the naïve strategy (same weight) and (2) a risk and return optimization strategy, based on the modern portfolio theory, for various sliding windows (12, 24 and 36 months). The authors concluded that all the strategies resulted in better returns when compared to Ibovespa. These results were maintained when analyzing the Sharpe Ratios of the various strategies and Ibovespa. The strategy with a moving average of 12 months proved to be the best one.

Examining the mean-variance efficiency of Brazilian indexes (Ibovespa, Brazil Index - IBrX50 and the Getúlio Vargas Foundation Index FGV100), Hagler and Brito (2007) rejected their efficiency. The tests involved data from the period between June 1989 and July 2003. The authors concluded that there was no triviality in choosing a benchmark for the passive management of 
third party funds, questioning the efficiency of the analyzed indexes. However, they highlighted that macroeconomic instability and high interest rates may have contributed to the inefficiency of the indexes.

DeMiguel, Garleppi, \& Uppal (2009) tested the naïve strategy for US market data, comparing it to 14 different optimization models, indicating the superiority of the former when compared to the others; the findings were obtained through the Sharpe Ratio and the certainty equivalent return. The choice for the naïve strategy is based on (i) the ease of operation (due to non-dependence of estimating the future based on historical parameters such as return and risk), and (ii) the use of this approach by investors. The authors indicate that the naïve strategy is more likely to produce better results the higher the number of assets involved - by leveraging the power of diversification. Empirical tests involved scenarios for 3, 9, 11, 21 and 24 assets.

Defying common sense, Levy and Roll (2010) used reverse engineering to indicate that small variations in mean and variance parameters within estimation errors may indicate that market indexes are efficient from the mean-variance point of view.

Thomé et al. (2011) tested minimum variance portfolios. The authors constructed portfolios with maximum participation limits for each share ranging from $10 \%$ to $100 \%$ (that is, with no limits). The portfolio with no weight limits was not superior to Ibovespa, but the portfolio with maximum weight of $10 \%$ was superior to Ibovespa. The latter portfolio, however, was not superior to a portfolio formed by the naïve strategy (equally weighted) and was surpassed by actively managed funds. The maximum $10 \%$ weight limit, according to the authors, ensured greater stability and composition uniformity of the portfolio at every quarter. The authors analyzed the period between April 1998 and December 2008.

Studying 677 daily observations concerning 45 assets between March 2009 and November 2011, Santos and Tessari (2012) compared the performance of Ibovespa to that of the naïve strategy and other optimization strategies. The results indicate that (a) the meanvariance strategy presented the best results in terms of return, followed by the minimum variance, naïve and Ibovespa strategies, and (b) the mean-variance and minimum variance strategies presented smaller standard deviations than the other two strategies (naïve and Ibovespa). The Sharpe Ratios of the mean-variance and minimum variance strategies are greater than those of the naïve and Ibovespa strategies. The authors point out that any differences in maximum asset allocation restrictions (being more flexible), analysis period, used algorithm and others can explain the different results previously presented by other authors.

Analyzing shares that made up Ibovespa between January 1998 and December 2011, Santiago and Leal (2015) formed portfolios based on the naïve strategy (from 6 to 16 assets per portfolio) and on minimum variance (with maximum weight of $10 \%$ ). The selection criterion, among the possible shares, was the greatest Sharpe Ratio. The naïve portfolios did not surpass Ibovespa or the minimum variance portfolio. The authors also compared the naïve portfolio to the Investment Shares Funds (Fundos de Investimento em Açôes, FIA), concluding that the naïve portfolio was equivalent to the latter.

This paper tests a period made up of 34 quarters, and offers 118 shares for portfolio formation. Other studies do not match these numbers. It is also the first known study to test New Ibovespa.

\section{Methodology}

\section{I Sample}

The 34 Ibovespa portfolios recalculated retroactively by the new methodology (New Ibovespa) between January 2003 and January 2014 were obtained from BM\&FBovespa (2014b). All in all, the sample considers 118 shares that comprised at least one of the 34 
mentioned portfolios. The returns of the Old Ibovespa and of New Ibovespa were also obtained from BM\&FBovespa (2014b).

The prices (adjusted for corporate events) of all the shares that made up these 34 portfolios (118 shares) were obtained from the Economática information system (for the period between August 30, 2002 and May 2, 2014).

The historical series of the daily Selic rate were obtained from Brazil's Central Bank's (Banco Central do Brasil) time series system (also for the period between August 30, 2002 and May 2, 2014).

\subsection{Formation of portfolios $T$}

The portfolio $\mathrm{T}$ was obtained with only Brazilian assets (shares traded in Bovespa and a risk free asset - considered as the Selic) and without allowing leverage (the possibility of short selling was discarded).

Table 1

\section{Changes in the names of certain shares}

\begin{tabular}{lccc}
\hline Original name & Current name & Original name & Current name \\
\hline BMEF3 & BVMF3 & LLXL3 & PRML3 \\
BRTO4 & OIBR4 & PCAR5 & PCAR4 \\
CLSC6 & CLSC4 & PRGA3 & BRFS3 \\
CESP4 & CESP5 & VCPA3 & FIBR3 \\
ECOD3 & VAGR3 & TLPP4 & VIVT4 \\
ELPL6 & ELPL4 & TSPP4 & VIVO4 \\
ITAU4 & ITUB4 & TCSL3 & TIMP3 \\
\hline
\end{tabular}

The composition of portfolio $T$, for each of the 34 analyzed four-month periods, is presented in Appendix A.

\subsection{Hypotheses and statistical approach}

The goal of this paper was to determine whether Ibovespa, Old and New, would be the best alternative for investors, considering investment possibilities (risky and risk free) in the Brazilian market.

Therefore, it is necessary to test the difference in return and the difference in variance between pairs of portfolio ((I) portfolio $\mathrm{T}$ versus New Ibovespa, (II) portfolio $\mathrm{T}$ versus Old
For each of the 34 (four-month) periods analyzed, the portfolio with shares that had the greatest Sharpe Ratio was calculated (portfolio T), offering for its composition the shares that made up Ibovespa (according to the new methodology) in the respective period (four months). Weekly returns were used for a four-month history (the four months previous to the effectiveness of the portfolio). Portfolio $\mathrm{T}$ was achieved by routines developed by the authors and carried out in Microsoft Excel.

Some shares that made up Ibovespa in at least one of the 34 periods analyzed are no longer traded, but their historical price series are still made available by Economática. Other shares changed their names, for several reasons. In this paper, the name changes presented in Table 1 were considered.
Ibovespa, and (III) New Ibovespa versus Old Ibovespa), plus the difference in the relationship between return and variance measured by the Sharpe Ratio (IS).

In this sense, the research hypotheses initially presented in the introduction of this paper can be developed into a generically null hypothesis $\left(\mathrm{H}_{0}\right)$ : that is, the equality of parameters hypothesis (mean, variance or Sharpe Ratio) between the above highlighted pairs and the alternative hypothesis $\left(\mathrm{H}_{\mathrm{a}}\right)$ : the superiority of one of the portfolios in the pair in terms of the parameter analyzed. Therefore, the set of hypotheses is: 
I - Pair of portfolios — portfolio T versus New Ibovespa:

$\mathrm{HI}-\mathrm{I}_{0}$ : mean of portfolio $\mathrm{T}=$ mean of $\mathrm{New}$ Ibovespa

$\mathrm{HI}-\mathrm{I}_{\mathrm{a}}$ : mean of portfolio $\mathrm{T} \geq$ mean of New Ibovespa

HI-II ${ }_{0}$ : variance of portfolio $\mathrm{T}=$ variance of New Ibovespa

$\mathrm{HI}-\mathrm{II}_{\mathrm{a}}$ : variance of portfolio $\mathrm{T} \neq$ variance of New Ibovespa

$\mathrm{HI}_{-} \mathrm{III}_{0}$ : IS of portfolio $\mathrm{T}=\mathrm{IS}$ of $\mathrm{New}$ Ibovespa

HI-III: IS of portfolio $\mathrm{T} \geq \mathrm{IS}$ of $\mathrm{New}$ Ibovespa

II - Pair of portfolios — portfolio T versus Old Ibovespa:

HII-I ${ }_{0}$ : mean of portfolio $\mathrm{T}=$ mean of Old Ibovespa

HII-I : mean of portfolio $T \geq$ mean of Old Ibovespa

HII-II ${ }_{0}$ : variance of portfolio $\mathrm{T}=$ variance of Old Ibovespa

HII-II : variance of portfolio $T \neq$ variance of Old Ibovespa

HII-III $_{0}$ : IS of portfolio $\mathrm{T}=\mathrm{IS}$ of Old Ibovespa

HII-III : IS of portfolio $\mathrm{T} \geq$ IS of Old Ibovespa

III - Pair of portfolios - New Ibovespa versus Old Ibovespa:

HIII-I ${ }_{0}$ : mean of New Ibovespa $=$ mean of Old Ibovespa

HIII-I : mean of New Ibovespa $\geq$ mean of Old Ibovespa

HIII-II ${ }_{0}$ : variance of New Ibovespa = variance of Old Ibovespa

HIII-II : variance of New Ibovespa $\neq$ variance of Old Ibovespa

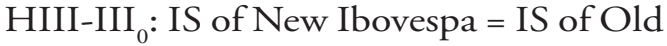
Ibovespa

HIII-III : IS of New Ibovespa $\geq$ IS of Old Ibovespa

For the mean test, the paired data variant was used, since both portfolios being compared are present on the same dates. Levine, Stephan, Krehbiel and Berenson (2012) indicate the use of paired tests for two interrelated populations. Lapponi (2000) emphasizes that, in these cases, the variable of interest is the difference between both pairs of samples rather than the samples themselves (since they are paired, both samples are of the same size). In this paper, the focus is on the historical series of the daily difference in the return of the portfolios, and not on the individual values themselves, which, according to Levine et al. (2012), also indicates the interrelated or paired population test. Costa (1977) indicates that reducing the sample to a single one made up of the differences increases the power of explanation of the test, when compared with unpaired samples: "whenever possible and justifiable, we should pair the data, because in this way we shall have an additional information that will lead us to statistically stronger results" (Costa, 1977, p. 109).

If the return distributions are normal distributions, the equality of the mean will be tested using the one-tailed t-test for paired data. If the return distributions are not normal distributions, the equality of the mean will be tested using the nonparametric Wilcoxon test for paired data, which, for one-tailed consideration, will be assumed as a symmetrical distribution. According to Fávero, Belfiore, Silva and Chan (2009), the Wilcoxon test is recommended to test the mean difference of two paired samples, and according to Maroco (2007) this test is used to compare two population means from paired data, replacing the t-test. Santiago and Leal (2015) and Thomé et al. (2011) used the Wilcoxon test.

The equality of variance test will be the F-test, when the distributions are normal, and Levene's test, when the distributions are not normal. The null hypothesis of the t-test, Wilcoxon, F-test and Levene is that of the equality of parameter (mean and variance, as appropriate). 
The normality of the distributions is tested using the Kolmogorov-Smirnov (KS) test, in which the null hypothesis is that distribution is normal and the alternative hypothesis is that distribution is not normal.

\section{Data Analysis}

It can be observed that the portfolios $\mathrm{T}$ formed for each of the four-month periods present a reduced number of shares compared to the number of shares present in New Ibovespa and, consequently, shares with great weight in the portfolio. It can also be observed that there is, every four months, a major change in the composition of the portfolio $\mathrm{T}$ (Table 2). The change in portfolio composition is credited by some authors, such as Jagannathan and $\mathrm{Ma}$ (2003), to errors in the estimation of historical returns. Jagannathan and $\mathrm{Ma}$ (2003) suggest the minimum variance portfolio strategy as an alternative to stabilize weights.

Table 2

Composition of Portfolio $\mathrm{T} \mathbf{x}$ Composition of New Ibovespa

\begin{tabular}{|c|c|c|c|c|c|c|c|c|}
\hline \multirow[b]{2}{*}{ Quarter } & \multicolumn{4}{|c|}{ Portfolio T } & \multicolumn{4}{|c|}{ New Ibovespa } \\
\hline & $\begin{array}{l}\text { Amount of } \\
\text { Shares }\end{array}$ & $\begin{array}{c}\% \text { Repeated } \\
\text { Shares from t-1 }\end{array}$ & $\begin{array}{c}\text { Greater } \\
\text { Weight } \\
\text { Share }\end{array}$ & $\begin{array}{c}\text { Weight } 3 \\
\text { Greater } \\
\text { Shares }\end{array}$ & $\begin{array}{l}\text { Amount } \\
\text { of Shares }\end{array}$ & $\begin{array}{c}\% \text { Repeated } \\
\text { Shares from } t-1\end{array}$ & $\begin{array}{c}\text { Greater } \\
\text { Weight } \\
\text { Share }\end{array}$ & $\begin{array}{c}\text { Weight } 3 \\
\text { Greater } \\
\text { Shares }\end{array}$ \\
\hline 1 & 7 & & $48.4 \%$ & $79.7 \%$ & 41 & & $18.4 \%$ & $33.6 \%$ \\
\hline 2 & 6 & $33.3 \%$ & $34.7 \%$ & $74.4 \%$ & 39 & $100.0 \%$ & $14.3 \%$ & $30.6 \%$ \\
\hline 3 & 7 & $42.9 \%$ & $26.7 \%$ & $78.5 \%$ & 37 & $100.0 \%$ & $14.6 \%$ & $32.6 \%$ \\
\hline 4 & 8 & $25.0 \%$ & $20.8 \%$ & $58.1 \%$ & 39 & $94.9 \%$ & $14.5 \%$ & $28.9 \%$ \\
\hline 5 & 2 & $0.0 \%$ & $62.2 \%$ & $100.0 \%$ & 40 & $97.5 \%$ & $15.0 \%$ & $30.7 \%$ \\
\hline 6 & 5 & $20.0 \%$ & $41.7 \%$ & $91.3 \%$ & 42 & $95.2 \%$ & $14.5 \%$ & $30.8 \%$ \\
\hline 7 & 7 & $14.3 \%$ & $23.7 \%$ & $61.2 \%$ & 44 & $95.5 \%$ & $14.5 \%$ & $31.4 \%$ \\
\hline 8 & 3 & $33.3 \%$ & $49.8 \%$ & $100.0 \%$ & 47 & $93.6 \%$ & $14.7 \%$ & $32.6 \%$ \\
\hline 9 & 7 & $0.0 \%$ & $56.3 \%$ & $81.4 \%$ & 48 & $95.8 \%$ & $15.8 \%$ & $35.6 \%$ \\
\hline 10 & 8 & $25.0 \%$ & $42.3 \%$ & $76.3 \%$ & 49 & $93.9 \%$ & $15.8 \%$ & $35.6 \%$ \\
\hline 11 & 7 & $14.3 \%$ & $30.0 \%$ & $77.9 \%$ & 51 & $90.2 \%$ & $15.7 \%$ & $33.9 \%$ \\
\hline 12 & 7 & $28.6 \%$ & $35.9 \%$ & $80.2 \%$ & 51 & $90.2 \%$ & $15.4 \%$ & $33.1 \%$ \\
\hline 13 & 8 & $12.5 \%$ & $26.7 \%$ & $67.6 \%$ & 54 & $90.7 \%$ & $14.8 \%$ & $32.8 \%$ \\
\hline 14 & 6 & $16.7 \%$ & $24.8 \%$ & $61.0 \%$ & 57 & $94.7 \%$ & $12.7 \%$ & $31.8 \%$ \\
\hline 15 & 8 & $0.0 \%$ & $47.4 \%$ & $85.2 \%$ & 61 & $90.2 \%$ & $15.7 \%$ & $35.5 \%$ \\
\hline 16 & 5 & $60.0 \%$ & $39.2 \%$ & $81.5 \%$ & 66 & $92.4 \%$ & $15.5 \%$ & $36.2 \%$ \\
\hline 17 & 6 & $0.0 \%$ & $36.3 \%$ & $77.1 \%$ & 66 & $97.0 \%$ & $14.7 \%$ & $33.3 \%$ \\
\hline 18 & 5 & $20.0 \%$ & $45.4 \%$ & $96.6 \%$ & 68 & $85.3 \%$ & $14.4 \%$ & $32.7 \%$ \\
\hline 19 & 1 & $100.0 \%$ & $100.0 \%$ & $100.0 \%$ & 55 & $100.0 \%$ & $14.0 \%$ & $32.4 \%$ \\
\hline 20 & 8 & $12.5 \%$ & $56.3 \%$ & $86.6 \%$ & 52 & $96.2 \%$ & $13.7 \%$ & $35.7 \%$ \\
\hline 21 & 12 & $16.7 \%$ & $28.3 \%$ & $55.7 \%$ & 51 & $98.0 \%$ & $13.3 \%$ & $34.5 \%$ \\
\hline 22 & 6 & $16.7 \%$ & $30.0 \%$ & $73.7 \%$ & 54 & $90.7 \%$ & $13.4 \%$ & $33.1 \%$ \\
\hline 23 & 7 & $0.0 \%$ & $36.4 \%$ & $77.3 \%$ & 57 & $93.0 \%$ & $12.9 \%$ & $32.3 \%$ \\
\hline 24 & 8 & $12.5 \%$ & $44.4 \%$ & $78.3 \%$ & 58 & $96.6 \%$ & $10.6 \%$ & $29.3 \%$ \\
\hline 25 & 8 & $25.0 \%$ & $29.5 \%$ & $68.8 \%$ & 58 & $96.6 \%$ & $12.8 \%$ & $31.9 \%$ \\
\hline 26 & 10 & $30.0 \%$ & $22.6 \%$ & $63.2 \%$ & 60 & $95.0 \%$ & $12.2 \%$ & $31.0 \%$ \\
\hline 27 & 7 & $42.9 \%$ & $32.6 \%$ & $67.0 \%$ & 63 & $92.1 \%$ & $10.7 \%$ & $29.4 \%$ \\
\hline 28 & 8 & $25.0 \%$ & $37.8 \%$ & $85.0 \%$ & 62 & $100.0 \%$ & $11.1 \%$ & $29.7 \%$ \\
\hline 29 & 12 & $41.7 \%$ & $28.0 \%$ & $57.0 \%$ & 65 & $92.3 \%$ & $10.1 \%$ & $27.0 \%$ \\
\hline 30 & 5 & $20.0 \%$ & $36.7 \%$ & $87.2 \%$ & 64 & $98.4 \%$ & $10.8 \%$ & $27.7 \%$ \\
\hline 31 & 13 & $7.7 \%$ & $34.6 \%$ & $60.0 \%$ & 66 & $97.0 \%$ & $9.4 \%$ & $26.9 \%$ \\
\hline 32 & 10 & $20.0 \%$ & $25.1 \%$ & $60.0 \%$ & 69 & $95.7 \%$ & $9.6 \%$ & $25.8 \%$ \\
\hline 33 & 8 & $0.0 \%$ & $26.2 \%$ & $70.0 \%$ & 73 & $93.2 \%$ & $8.3 \%$ & $23.4 \%$ \\
\hline 34 & 11 & $18.2 \%$ & $16.3 \%$ & $47.8 \%$ & 72 & $97.2 \%$ & $8.6 \%$ & $22.8 \%$ \\
\hline
\end{tabular}


Comparative analysis of the return and risk of the portfolio $\mathrm{T}$ in New Ibovespa and Old Ibovespa will be divided into two parts: (i) the entire period (composed of the 34 four-month periods) and (ii) the individual periods (composed of each four-month period individually).

\section{I Entire period}

Altogether, 2.805 daily returns over 34 four-month periods were analyzed. All portfolios traded in over $99.8 \%$ of the days. The Kolmogorov-Smirnov test rejected the normality of return distributions for the entire period for the portfolio $T$ ( $p$-value of 0.000), for New Ibovespa (p-value 0.000) and for Old Ibovespa ( $\mathrm{p}$-value of 0.000$)$.

The average daily return in the entire period (January 1, 2003 to April 30, 2014) (i) for the portfolio $\mathrm{T}$ was $0.111 \%$ p.d. (ii) for New Ibovespa was $0.079 \%$ p.d. and (iii) for Old Ibovespa was $0.070 \%$ p.d. The average daily return of the portfolio $T$ is statistically superior to New Ibovespa ( $p$-value of the nonparametric test, for one-tailed paired data - assuming symmetrical distribution, is 0.063 ), and also to Old Ibovespa ( $\mathrm{p}$-value of the nonparametric test, for one-tailed paired data - assuming symmetrical distribution, is 0.012). The average daily return of New Ibovespa is statistically superior to Old Ibovespa ( $p$-value of the nonparametric test for one-tailed paired data - assuming symmetrical distribution, is 0.078).

The standard deviation of daily returns throughout the period (i) for the portfolio $\mathrm{T}$ was $1.61 \%$, (ii) for New Ibovespa was $1.74 \%$, and (iii) for Old Ibovespa was $1.79 \%$. The standard deviation of daily returns of the portfolio $\mathrm{T}$ is statistically different from the standard deviation of daily returns of New Ibovespa (p-value of the Levene test is 0.001) and also from Old Ibovespa ( $\mathrm{p}$-value of the Levene test is 0.000). The standard deviation of New Ibovespa daily returns is statistically different from the standard deviation of daily returns of Old Ibovespa ( $\mathrm{p}$-value of the Levene test is 0.071).

The results indicate that the portfolio $T$ dominates New Ibovespa and Old Ibovespa (it presents greater return and smaller standard deviation). Therefore, Ibovespa (New or Old) would not be part of the set of efficient portfolios (ex post). There are also indications that New Ibovespa dominates Old Ibovespa (greater return and smaller standard deviation).

Regarding excess return (return above risk free asset rate), the results are the same (even considering that the risk free asset rate was variable over time). The average daily return of the risk free asset, throughout the period, is $0.049 \%$ p.d..

The Sharpe ratio was not statistically tested, because the daily IS was not calculated (its calculation requires standard deviation). However, with the above indications, it can be said that the Sharpe Ratio of the portfolio T (0.0389) is greater than New Ibovespa (0.0173) and Old Ibovespa (0.0117). The same could be said about the superiority, measured by the Sharpe Ratio, of New Ibovespa compared to Old Ibovespa.

Thus, considering the entire period, the portfolio $T$ would have been a better investment alternative. The research hypotheses listed in item 3.3, for the entire period, were answered with the tests above mentioned.

\subsection{Individual periods}

Considering each of the 34 four-month periods, Table 3 presents the result of the normality test of return distributions - the hypothesis of normality was not rejected for any portfolio (portfolio T, New Ibovespa or Old Ibovespa) or any of the 34 four-month periods. 
Table 3

Normality Test (p-value of the Kolmogorov-Smirnov Test)

\begin{tabular}{cccc|cccc}
\hline Quarter & Portfolio T & New Ibovespa & Old Ibovespa & Quarter & Portfolio T & New Ibovespa & Old Ibovespa \\
\hline 1 & 0.880 & 0.924 & 0.946 & 18 & 0.235 & 0.553 & 0.618 \\
2 & 0.783 & 0.951 & 0.854 & 19 & 0.507 & 0.759 & 0.677 \\
3 & 0.998 & 0.875 & 0.887 & 20 & 0.955 & 0.274 & 0.496 \\
4 & 0.871 & 0.997 & 0.992 & 21 & 0.753 & 0.343 & 0.377 \\
5 & 0.914 & 0.812 & 0.925 & 22 & 0.659 & 0.412 & 0.346 \\
6 & 0.965 & 0.933 & 0.726 & 23 & 0.863 & 0.982 & 0.988 \\
7 & 0.698 & 0.292 & 0.442 & 24 & 0.864 & 0.524 & 0.985 \\
8 & 0.656 & 0.766 & 0.628 & 25 & 0.498 & 0.479 & 0.639 \\
9 & 0.488 & 0.572 & 0.635 & 26 & 0.520 & 0.303 & 0.304 \\
10 & 0.768 & 0.836 & 0.820 & 27 & 0.510 & 0.969 & 0.999 \\
11 & 0.804 & 0.638 & 0.449 & 28 & 0.894 & 0.485 & 0.626 \\
12 & 0.909 & 0.889 & 0.723 & 29 & 0.263 & 0.782 & 0.978 \\
13 & 0.194 & 0.879 & 0.658 & 30 & 0.814 & 0.995 & 0.924 \\
14 & 0.219 & 0.483 & 0.497 & 31 & 0.830 & 0.934 & 0.967 \\
15 & 0.939 & 0.566 & 0.723 & 32 & 0.632 & 0.770 & 0.600 \\
16 & 0.410 & 0.572 & 0.566 & 33 & 0.867 & 0.944 & 0.988 \\
17 & 0.924 & 0.986 & 0.979 & 34 & 0.915 & 0.532 & 0.777 \\
\hline
\end{tabular}

Table 4 presents, on a daily basis, the average return, the standard deviation and the Sharpe Ratio for each four-month period (1-34) and for (i) the portfolio T, (ii) New Ibovespa, and (iii) Old Ibovespa.

Table 4

Daily Average Return, Standard Deviation and Sharpe Ratio (IS) for each one of the 34 fourmonth periods analyzed for (i) portfolio T, (ii) New Ibovespa and (iii) Old Ibovespa

\begin{tabular}{|c|c|c|c|c|c|c|c|c|c|}
\hline \multirow[b]{2}{*}{ Quarter } & \multicolumn{3}{|c|}{ Portfolio T } & \multicolumn{3}{|c|}{ New Ibovespa } & \multicolumn{3}{|c|}{ Old Ibovespa } \\
\hline & $\begin{array}{l}\text { Average } \\
\text { Return }\end{array}$ & $\begin{array}{l}\text { Std. } \\
\text { Dev. }\end{array}$ & IS & $\begin{array}{l}\text { Average } \\
\text { Return }\end{array}$ & $\begin{array}{l}\text { Std. } \\
\text { Dev. }\end{array}$ & IS & $\begin{array}{l}\text { Average } \\
\text { Return }\end{array}$ & $\begin{array}{l}\text { Std. } \\
\text { Dev. }\end{array}$ & IS \\
\hline 1 & $0.00 \%$ & $1.20 \%$ & $-7.36 \%$ & $0.14 \%$ & $1.40 \%$ & $3.62 \%$ & $0.15 \%$ & $1.78 \%$ & $3.27 \%$ \\
\hline 2 & $0.47 \%$ & $1.41 \%$ & $27.10 \%$ & $0.25 \%$ & $1.16 \%$ & $14.12 \%$ & $0.24 \%$ & $1.42 \%$ & $10.30 \%$ \\
\hline 3 & $0.46 \%$ & $1.51 \%$ & $25.75 \%$ & $0.39 \%$ & $1.22 \%$ & $26.62 \%$ & $0.46 \%$ & $1.36 \%$ & $28.72 \%$ \\
\hline 4 & $-0.26 \%$ & $2.19 \%$ & $-14.78 \%$ & $-0.15 \%$ & $1.98 \%$ & $-10.60 \%$ & $-0.13 \%$ & $2.23 \%$ & $-8.46 \%$ \\
\hline 5 & $0.37 \%$ & $2.02 \%$ & $15.36 \%$ & $0.22 \%$ & $1.66 \%$ & $9.66 \%$ & $0.19 \%$ & $1.84 \%$ & $7.42 \%$ \\
\hline 6 & $0.21 \%$ & $1.42 \%$ & $10.21 \%$ & $0.26 \%$ & $1.07 \%$ & $18.32 \%$ & $0.18 \%$ & $1.15 \%$ & $9.93 \%$ \\
\hline 7 & $-0.12 \%$ & $1.66 \%$ & $-11.41 \%$ & $-0.04 \%$ & $1.56 \%$ & $-6.73 \%$ & $-0.05 \%$ & $1.70 \%$ & $-7.08 \%$ \\
\hline 8 & $0.08 \%$ & $1.90 \%$ & $0.57 \%$ & $0.20 \%$ & $1.31 \%$ & $9.67 \%$ & $0.15 \%$ & $1.58 \%$ & $5.07 \%$ \\
\hline 9 & $0.24 \%$ & $1.38 \%$ & $12.56 \%$ & $0.24 \%$ & $1.46 \%$ & $11.54 \%$ & $0.23 \%$ & $1.43 \%$ & $10.96 \%$ \\
\hline 10 & $0.31 \%$ & $1.74 \%$ & $14.11 \%$ & $0.24 \%$ & $1.44 \%$ & $12.66 \%$ & $0.24 \%$ & $1.40 \%$ & $13.05 \%$ \\
\hline 11 & $-0.03 \%$ & $1.90 \%$ & $-4.62 \%$ & $-0.09 \%$ & $1.87 \%$ & $-7.86 \%$ & $-0.11 \%$ & $1.86 \%$ & $-8.75 \%$ \\
\hline 12 & $0.26 \%$ & $0.91 \%$ & $22.78 \%$ & $0.21 \%$ & $1.19 \%$ & $13.23 \%$ & $0.27 \%$ & $1.20 \%$ & $17.95 \%$ \\
\hline 13 & $0.12 \%$ & $1.66 \%$ & $4.40 \%$ & $0.12 \%$ & $1.61 \%$ & $4.21 \%$ & $0.13 \%$ & $1.65 \%$ & $5.10 \%$ \\
\hline 14 & $0.07 \%$ & $1.63 \%$ & $1.84 \%$ & $0.16 \%$ & $1.64 \%$ & $6.76 \%$ & $0.14 \%$ & $1.64 \%$ & $5.88 \%$ \\
\hline 15 & $0.17 \%$ & $1.74 \%$ & $7.61 \%$ & $0.25 \%$ & $1.93 \%$ & $10.74 \%$ & $0.22 \%$ & $1.91 \%$ & $9.26 \%$ \\
\hline 16 & $0.06 \%$ & $2.36 \%$ & $0.58 \%$ & $0.09 \%$ & $2.31 \%$ & $2.14 \%$ & $0.10 \%$ & $2.24 \%$ & $2.56 \%$ \\
\hline 17 & $-0.10 \%$ & $1.46 \%$ & $-9.88 \%$ & $-0.25 \%$ & $1.85 \%$ & $-15.83 \%$ & $-0.22 \%$ & $1.76 \%$ & $-15.11 \%$ \\
\hline 18 & $0.32 \%$ & $4.26 \%$ & $6.26 \%$ & $-0.32 \%$ & $5.07 \%$ & $-7.23 \%$ & $-0.35 \%$ & $4.96 \%$ & $-8.03 \%$ \\
\hline 19 & $0.07 \%$ & $0.34 \%$ & $7.70 \%$ & $0.30 \%$ & $2.57 \%$ & $9.98 \%$ & $0.32 \%$ & $2.51 \%$ & $10.79 \%$ \\
\hline 20 & $0.16 \%$ & $0.71 \%$ & $17.44 \%$ & $0.18 \%$ & $1.75 \%$ & $8.15 \%$ & $0.23 \%$ & $1.78 \%$ & $10.76 \%$ \\
\hline 21 & $0.20 \%$ & $1.39 \%$ & $12.35 \%$ & $0.24 \%$ & $1.57 \%$ & $12.88 \%$ & $0.25 \%$ & $1.57 \%$ & $13.93 \%$ \\
\hline 22 & $-0.04 \%$ & $1.37 \%$ & $-5.52 \%$ & $0.00 \%$ & $1.21 \%$ & $-3.09 \%$ & $-0.01 \%$ & $1.21 \%$ & $-3.73 \%$ \\
\hline
\end{tabular}




\begin{tabular}{cccccccccc}
\hline & \multicolumn{3}{c}{ Portfolio T } & \multicolumn{3}{c}{ New Ibovespa } & \multicolumn{3}{c}{ Old Ibovespa } \\
\cline { 2 - 10 } Quarter & $\begin{array}{c}\text { Average } \\
\text { Return }\end{array}$ & $\begin{array}{c}\text { Std. } \\
\text { Dev. }\end{array}$ & IS & $\begin{array}{c}\text { Average } \\
\text { Return }\end{array}$ & $\begin{array}{c}\text { Std. } \\
\text { Dev. }\end{array}$ & IS & $\begin{array}{c}\text { Average } \\
\text { Return }\end{array}$ & $\begin{array}{c}\text { Std. } \\
\text { Dev. }\end{array}$ & IS \\
\hline 23 & $0.20 \%$ & $1.54 \%$ & $10.32 \%$ & $-0.04 \%$ & $1.52 \%$ & $-5.35 \%$ & $-0.03 \%$ & $1.53 \%$ & $-4.51 \%$ \\
24 & $0.08 \%$ & $0.90 \%$ & $4.54 \%$ & $0.17 \%$ & $1.28 \%$ & $9.85 \%$ & $0.08 \%$ & $1.07 \%$ & $3.82 \%$ \\
25 & $0.13 \%$ & $1.07 \%$ & $8.19 \%$ & $-0.04 \%$ & $1.04 \%$ & $-8.39 \%$ & $-0.05 \%$ & $1.05 \%$ & $-9.15 \%$ \\
26 & $-0.01 \%$ & $1.51 \%$ & $-3.95 \%$ & $-0.15 \%$ & $1.63 \%$ & $-11.93 \%$ & $-0.17 \%$ & $1.73 \%$ & $-12.19 \%$ \\
27 & $0.11 \%$ & $1.30 \%$ & $5.31 \%$ & $0.06 \%$ & $1.60 \%$ & $1.23 \%$ & $0.02 \%$ & $1.77 \%$ & $-1.25 \%$ \\
28 & $0.14 \%$ & $0.75 \%$ & $13.76 \%$ & $0.09 \%$ & $1.11 \%$ & $4.92 \%$ & $0.11 \%$ & $1.17 \%$ & $6.24 \%$ \\
29 & $-0.08 \%$ & $1.13 \%$ & $-9.65 \%$ & $-0.06 \%$ & $1.46 \%$ & $-6.39 \%$ & $-0.08 \%$ & $1.66 \%$ & $-6.68 \%$ \\
30 & $0.08 \%$ & $0.94 \%$ & $5.95 \%$ & $0.10 \%$ & $1.05 \%$ & $6.76 \%$ & $0.09 \%$ & $1.17 \%$ & $5.43 \%$ \\
31 & $0.00 \%$ & $1.08 \%$ & $-2.98 \%$ & $-0.02 \%$ & $1.09 \%$ & $-4.08 \%$ & $-0.10 \%$ & $1.16 \%$ & $-11.01 \%$ \\
32 & $-0.04 \%$ & $1.04 \%$ & $-6.36 \%$ & $-0.10 \%$ & $1.25 \%$ & $-10.54 \%$ & $-0.12 \%$ & $1.47 \%$ & $-10.23 \%$ \\
33 & $0.20 \%$ & $1.13 \%$ & $14.49 \%$ & $0.08 \%$ & $1.00 \%$ & $4.42 \%$ & $0.04 \%$ & $1.23 \%$ & $0.64 \%$ \\
34 & $-0.04 \%$ & $1.25 \%$ & $-6.72 \%$ & $0.02 \%$ & $1.25 \%$ & $-1.77 \%$ & $0.01 \%$ & $1.30 \%$ & $-2.65 \%$ \\
\hline
\end{tabular}

Comparing the return of the portfolio $\mathrm{T}$ to New Ibovespa in each of the four-month periods, through the one-tailed t-test for paired data, it can be said that the return of the portfolio $T$ was statistically superior to that of New Ibovespa in five four-month periods ( $14.7 \%$ of the cases): 2 (p-value 0.048), 18 (0.051), 23 (0.035), 25 (0.056) and 26 (0.086). The return of New Ibovespa did not statistically surpass the return of the portfolio $\mathrm{T}$ in any of the four-month periods.

Comparing the standard deviation of the portfolio $T$ with the standard deviation of New Ibovespa in each of the four-month periods, through the F-test, it can be said that (i) the standard deviation of the portfolio $\mathrm{T}$ was statistically smaller than that of New Ibovespa in nine four-month periods (26.5\% of cases), 12 (p-value 0.020), 17 (0.029), 19 (0.000), 20 (0.000), 24 (0.002), 27 (0.058), 28 (0.001), 29 (0.020), and $32(0.092)$ and (ii) the standard deviation of the portfolio $\mathrm{T}$ was statistically greater than that of New Ibovespa in six fourmonth periods $(17.6 \%$ of cases): 2 (p-value $0.076), 3$ (0.054), 5 (0.071), 6 (0.011), 8 (0.001), and $10(0.091)$. The lower number of shares in the portfolio $T$ when compared to New Ibovespa, which could restrict the diversification capacity of the portfolio $\mathrm{T}$, did not hinder the performance, in terms of risk, of the portfolio $\mathrm{T}$ when compared to New Ibovespa.

The portfolio $\mathrm{T}$ dominated New Ibovespa in thirteen four-month periods. Those in which (i) the return of the portfolio $\mathrm{T}$ was statistically greater than that of New Ibovespa and the standard deviation was statistically smaller or equal (four-month periods 18, 23, 25 and 26) or (ii) the standard deviation of the portfolio $\mathrm{T}$ was statistically smaller than that of New Ibovespa and the return was statistically equal $(12,17,19,20$, 24, 27, 28, 29 and 32). New Ibovespa dominated the portfolio $\mathrm{T}$ in five four-month periods: 3,5 , 6, 8 and 10 (smaller risk and equal return). In terms of dominance, the portfolio $\mathrm{T}$ dominated New Ibovespa in $72.2 \%$ of cases in which there was dominance (13 in 18).

The details are not displayed, such as for comparison between the portfolio $\mathrm{T}$ and New Ibovespa, but the portfolio $\mathrm{T}$ dominated Old Ibovespa in fifteen of the eighteen four-month periods in which there was dominance $(83.3 \%$ of cases). New Ibovespa dominated Old Ibovespa in seven of the nine cases in which there was dominance $(77.8 \%$ of cases).

Since the daily Sharpe Ratio was not calculated (because it requires standard deviation), its analysis was not carried out within the fourmonth periods (as well as the analysis of the mean and of standard deviation), but between them (considering the 34 quarterly measures). The average Sharpe Ratio in the 34 four-month periods was 0.049 for portfolio T, 0.030 for New Ibovespa, and 0.021 for Old Ibovespa. The distribution of the 34 Sharpe Ratios is normal for the portfolio $\mathrm{T}$ ( $\mathrm{p}$-value of the Kolmogorov- 
Smirnov test is 0.945), for New Ibovespa (p-value 0.871 ) and for Old Ibovespa (p-value 0.842). The average Sharpe Ratio for the portfolio $T$ is statistically greater than that of New Ibovespa ( $\mathrm{p}$-value of the tailed $\mathrm{t}$-test for paired data is 0.067 ) and is also statistically superior to Old Ibovespa (p-value 0.014). The average Sharpe Ratio of New Ibovespa is statistically greater than that of Old Ibovespa (p-value 0.036). In 52.9\% (18 of 34) of the four-month periods, the Sharpe Ratio of the portfolio $\mathrm{T}$ was greater than that of New Ibovespa. In 58.5\% (20 of 34) of the fourmonth periods, the Sharpe Ratio of the portfolio T was greater than that of Old Ibovespa. In $61.8 \%$ (21 of 37) of the four-month periods, the Sharpe Ratio of New Ibovespa was higher than that of Old Ibovespa.

Considering only the four-month period with a positive Sharpe Ratio (19 four-month periods), the average Sharpe Ratio was 0.115 for the portfolio T, 0.103 for New Ibovespa, and 0.094 for Old Ibovespa. The distribution of the 19 positive Sharpe Ratios is normal for the portfolio $\mathrm{T}$ (p-value of the Kolmogorov-Smirnov test is 0.983 ), for New Ibovespa (p-value 0.814) and for Old Ibovespa ( $\mathrm{p}$-value 0.502). The average Sharpe Ratio for the portfolio $T$ is not statistically greater than that of New Ibovespa (p-value of the tailed t-test for paired data is 0.218 ) and is, however, statistically greater than that of Old Ibovespa (p-value 0.065). The average Sharpe Ratio of New Ibovespa is statistically greater than that of Old Ibovespa (p-value 0.098). In 47.4\% (9 of 19) of the four-month periods, the Sharpe Ratio of the portfolio $\mathrm{T}$ was greater than that of New Ibovespa. In $57.9 \%$ (11 of 19) of the four-month periods, the Sharpe Ratio of the portfolio $\mathrm{T}$ was greater than that of Old Ibovespa. In 52.6\% (10 of 19) of the four-month periods, the Sharpe Ratio of New Ibovespa was greater than that of Old Ibovespa.

\subsection{Robustness}

The robustness analysis focused on the comparison, for the entire period, between the portfolio $T$ and New Ibovespa. One can imagine that the four-month periods in which the portfolio $\mathrm{T}$ consists of only a few assets is capable of distorting the results presented herein, favoring the portfolio T over New Ibovespa. It is noteworthy that the portfolios were set up with the history of the four-month period previous to their effectiveness, and, therefore, it would have been necessary that these few assets would have had favorable results over two consecutive four-month periods - the portfolio's estimation four-month period and the portfolio's four-month period of its effectiveness.

It can also be observed that the small number of assets in the portfolio $T$ could impair its ability to diversify. On the one hand, since Evans and Archer (1968), it has been show that it is not necessary a large number of assets to largely capture the effects of diversification (in Brazil, see, for example, Oliveira \& Paula, 2008). On the other hand, Chance Shynkevich and Yang (2011) disagree in general terms about this standard line of thought, recommending a greater amount of shares. Studies related to the specific topic of this paper indicate the superiority of portfolios formed by a larger number of assets (DeMiguel et al., 2009; Thomé et al., 2011).

The correlation between the number of assets in the portfolio $\mathrm{T}$ and the module of the difference between the return of the portfolio $T$ and the return of New Ibovespa for each fourmonth period was calculated, obtaining -0.35 (p-value 0.0427). This correlation indicates that, the smaller the amount of assets in the portfolio $T$, the greater the module of the difference between the returns of the portfolio $T$ and the New Ibovespa portfolio. The correlation between the number of assets in the portfolio $T$ and the module of the difference of the standard deviation of returns (between the portfolio $T$ and New Ibovespa) is -0.49 (p-value 0.0035), indicating that the smaller the amount of assets in the portfolio $\mathrm{T}$, the greater the module of the difference between standard deviations. The module difference does not indicate which of the two portfolios was superior and this analysis, although it presents indications, is not conclusive. 
The amount of assets per portfolio $\mathrm{T}$ varies from 1 to 13 assets over the 34 four-month periods analyzed. There is a portfolio $\mathrm{T}$ with only one asset, and also one portfolio $\mathrm{T}$ with thirteen assets. Table 5 presents the number of portfolios $\mathrm{T}$ for each amount of assets.

Table 5

Amount of assets per portfolio and number of portfolios (absolute and relative)

\begin{tabular}{ccc}
\hline Amount of Assets & Number of Portfolios T & Proportion of Total Portfolios T \\
\hline 1 & 1 & $2.9 \%$ \\
2 & 1 & $2.9 \%$ \\
3 & 1 & $2.9 \%$ \\
4 & 0 & $0.0 \%$ \\
5 & 4 & $11.8 \%$ \\
6 & 4 & $11.8 \%$ \\
7 & 8 & $23.5 \%$ \\
8 & 9 & $26.5 \%$ \\
9 & 0 & $0.0 \%$ \\
10 & 2 & $5.9 \%$ \\
11 & 1 & $2.9 \%$ \\
12 & 2 & $5.9 \%$ \\
13 & 1 & $2.9 \%$ \\
Total & $\mathbf{3 4}$ & $\mathbf{1 0 0} \%$ \\
\hline
\end{tabular}

It can be observed in Table 5 that $20.6 \%$ of the portfolios $\mathrm{T}$ have five assets or less. Table 6 presents the average returns of the portfolio $T$ and of the New Ibovespa portfolio, the standard deviation of the portfolio $T$ and the New Ibovespa portfolio, the p-value of mean equality test, and the $\mathrm{p}$-value of the variance equality test, if the portfolios with up to a certain number of assets (ranging from 1 to 5 ) were eliminated from the sample of the entire period. Normality of return was tested for each exclusion scenario. The p-value of the Kolmogorov-Smirnov test indicates that the distributions in Table 6 are not normal ( $\mathrm{p}$ test value for the distributions of both portfolios with the exclusion of one to four assets is 0.000 , and, for the exclusion of five assets, the p-value of the distribution of the portfolio $\mathrm{T}$ is 0.002 and of New Ibovespa is 0.014).

\section{Table 6}

Portfolio T Performance Versus New Ibovespa Performance if Periods in which the Portfolio T had a Number of Assets that was Equal to or Smaller than a Certain Number of Assets were Eliminated (from 1 to 5 Assets)

\begin{tabular}{ccccccc}
\hline & \multicolumn{2}{c}{ Portfolio T } & \multicolumn{2}{c}{ New Ibovespa } & \multicolumn{2}{c}{ Equality Test } \\
\cline { 2 - 7 } $\begin{array}{c}\text { Amount of } \\
\text { Assets }\end{array}$ & Return & $\begin{array}{c}\text { Standard } \\
\text { Deviation }\end{array}$ & Return & $\begin{array}{c}\text { Standard } \\
\text { Deviation }\end{array}$ & $\begin{array}{c}\text { Mean } \\
(\mathbf{p} \text {-value })\end{array}$ & $\begin{array}{c}\text { Variance } \\
(\mathbf{p} \text {-value) }\end{array}$ \\
\hline 0 & $0.111 \%$ & $1.61 \%$ & $0.079 \%$ & $1.74 \%$ & 0.063 & 0.001 \\
1 & $0.113 \%$ & $1.63 \%$ & $0.073 \%$ & $1.71 \%$ & 0.050 & 0.078 \\
2 & $0.104 \%$ & $1.61 \%$ & $0.068 \%$ & $1.71 \%$ & 0.063 & 0.042 \\
3 & $0.105 \%$ & $1.60 \%$ & $0.063 \%$ & $1.73 \%$ & 0.067 & 0.013 \\
4 & $0.105 \%$ & $1.60 \%$ & $0.063 \%$ & $1.73 \%$ & 0.067 & 0.013 \\
5 & $0.096 \%$ & $1.40 \%$ & $0.068 \%$ & $1.48 \%$ & 0.085 & 0.018 \\
\hline
\end{tabular}


It can be observed that, even excluding the four-month periods in which the portfolio $T$ was comprised of less than five assets, the portfolio $T$ would have been superior to New Ibovespa in return (greater) and risk (smaller). For scenarios in which the portfolios $T$ with over five assets ( 6 to 12 , successively) are excluded, the average equality tests indicate that (i) the return of the portfolio $T$ was equal to the return of the New Ibovespa portfolio, and (ii) that the variance of the portfolio $T$ was smaller than the variance of New Ibovespa. Thus, the portfolio $T$ would have been better than New Ibovespa in all exclusion scenarios.

Additionally, analyses with no extreme values were carried out. Two separate scenarios were analyzed:

In the first one, values above and below 3.09 standard deviations were eliminated. If the distribution was normal, it would be equivalent to eliminate $0.2 \%$ of the observations $(0.1 \%$ on each side, assuming normal distribution). In total, for the portfolio $T, 36$ observations were eliminated (1.28\% of the 2.805 values), and 35 observations of New Ibovespa $(1.25 \%$ of the 2.805 values). Observations fell to 2.752, distributions continued to be not normal (p-value of the KS test was 0.001 and 0.014 for portfolio $\mathrm{T}$ and New Ibovespa, respectively). The average return of the portfolio $\mathrm{T}$ was $0.1064 \%$ and of New Ibovespa was $0.0684 \%$, portfolio $T$ being statistically higher ( $\mathrm{p}$-value of the non-parametric test 0.065 ). The standard deviation of the portfolio $\mathrm{T}$ was $1.39 \%$ and of New Ibovespa was $1.47 \%$, portfolio $\mathrm{T}$ being statistically better ( $\mathrm{p}$-value of the non-parametric test 0.001 ).

In the second scenario, the values above and below 2.58 standard deviations (equivalent to $1.0 \%$ of observations, if distributions were normal) were eliminated. In all, 63 observations (2.25\%) of the portfolio $\mathrm{T}$ and 61 observations (2.17\%) of New Ibovespa were eliminated, with 2.711 observations remaining. The portfolio $T$ was statistically superior to New Ibovespa in terms of average return $(0.1085 \%$ versus $0.0750 \%$, with p-value of the non-parametric test equal to 0.053), and in terms of standard deviation (1.33\% versus
$1.40 \%, \mathrm{p}$-value of the non-parametric test equal to 0.001$)$.

These analyses with elimination of extreme values continue to indicate the superiority of the portfolio $\mathrm{T}$ when compared to New Ibovespa.

\section{Final Considerations}

Modern portfolio theory says that there is a risky assets' portfolio that all investors should have - the portfolio $T$. The portfolio $T$ would be one of the portfolios in the efficient investment frontier. The other portfolios in the efficient investment frontier, even not being dominated by any other risky asset portfolio, would not be the best alternative for investors.

Is Ibovespa this portfolio $T$ ? Is there a portfolio that would be better for investor? Is there a portfolio that would dominate Ibovespa?

Thirty four four-month periods (from January 1, 2003 to April 30, 2014) were studied, analyzing Old Ibovespa, New Ibovespa and the portfolio $\mathrm{T}$ (the latter calculated from modern portfolio theory, considering the Selic as the risk free asset).

For the entire period, the portfolio $\mathrm{T}$ presented statistically greater returns and smaller standard deviations than New Ibovespa and Old Ibovespa, and is thus a better alternative for investors. New Ibovespa and Old Ibovespa were dominated by the portfolio T (expost). The portfolio T's Sharpe Ratio was also higher than New Ibovespa and Old Ibovespa. New Ibovespa, in turn, dominated Old Ibovespa (greater return and smaller risk).

In accepting the assumptions made in this study, New Ibovespa or Old Ibovespa are not the best investment alternatives.

Analyzing each of the four-month periods individually, it was observed that, in thirteen of the eighteen four-month periods in which there was dominance, the portfolio $\mathrm{T}$ dominated New Ibovespa (when the return of the portfolio $\mathrm{T}$ was statistically greater than that of New Ibovespa and/ or the standard deviation of the portfolio $\mathrm{T}$ was statistically smaller than that of New Ibovespa). New Ibovespa dominated the portfolio $T$ in only 
five of the eighteen cases. When all 34 four-month periods are considered, the average Sharpe Ratio for the portfolio $T$ was statistically greater than the average Sharpe Ratio for New Ibovespa, and is individually greater in $52.9 \%$ of cases. When only the four-month periods in which the Sharpe Ratio was positive are considered, there was no statistical superiority in either of the two portfolios (portfolio $\mathrm{T}$ and New Ibovespa), and in $47.4 \%$ of the four-month periods the Sharpe Ratio of the portfolio T surpassed New Ibovespa.

The limitations of the portfolio $\mathrm{T}$ are as follows: (i) few number of component shares, (ii) consequent large weight of individual shares in the portfolio, and (iii) major change in the composition of the same (see Table 2).

The limitations of this paper are in the definition of the assumption (including the choice of the risk free asset), in the alternatives used for historical data and periodicity, and in the assumption that future expectations are well represented by the historical data obtained over the estimation period.

\section{References}

BM\&FBOVESPA. (2014a). O que éo Ibovespa? Recuperado de http://www. bmfbovespa.com.br/indices/ResumoIndice. aspx?Indice $=$ Ibovespa\&idioma $=\mathrm{pt}-\mathrm{br}$

BM\&FBOVESPA. (2014b). Série retroativa do Ibovespa com base na metodologia adotada em Setembro de 2013. Recuperado de http://www. bmfbovespa.com.br/Indices/download/SERIERETROATIVA-DO-IBOV-METODOLOGIAVALIDA-A-PARTIR-09-2013.pdf

Bruni, A. L., \& Famá, R. (1998). Moderna teoria de portfólios: É possível captar, na prática, os benefícios decorrentes de sua utilização? Resenha da BM\&F, (128), 19-34.

Chance, D. M., Shynkevich, A., \& Yang, T. (2011). Experimental evidence on portfolio size and diversification: Human biases in naive security selection and portfolio construction. Financial Review, 46(3), 427-457.
Copeland, T., Weston, J. F., \& Shastri, K. (2005). Financial theory and corporate policy (4th ed.). Boston: Pearson.

Costa, P. L. O., Neto. (1977). Estatística. São Paulo: Edgard Blücher.

DeMiguel, V., Garlappi, L., \& Uppal, R. (2009). Optimal versus naive diversification: How inefficient is the $1 / \mathrm{n}$ portfolio strategy? The Review of Financial Studies, 22(5), 1915-1953.

Elton, E. J., Gruber, M. J., Brown, S. J., \& Goetzmann, W. N. (2004). Moderna teoria de carteiras e análise de investimentos. São Paulo: Atlas.

Evans, J. L., \& Archer, S. H. (1968). Diversification and the reduction of dispersion: An empirical analysis. Journal of Finance, 23(5), 761-767.

Fávero, L. P., Belfiore, P., Silva, F. L., \& Chan, B. L. (2009). Análise de dados: Modelagem multivariada para tomada de decisóes. Rio de Janeiro: Elsevier.

Hagler, C. E. M., \& Brito, R. D. O. (2007). Sobre a eficiência dos índices de ações brasileiros. Revista de Administração, 42(1), 74-85.

Hieda, A., \& Oda, A. L. (1998). Um estudo sobre a utilização de dados históricos no modelo de Markowitz aplicado à bolsa de valores de São Paulo. Seminários em Administração, São Paulo, SP, Brasil, 9. Recuperado de http://www.semead. com.br/edicoes-anteriores-2/

Jagannathan, R., \& Ma, T. (2003). Risk reduction in large portfolios: Why imposing the wrong constraints helps. Journal of Finance, 58(4), 1651-1684.

Lapponi, J. C. (2000). Estatística usando Excel. São Paulo: Lapponi Treinamento e Editora.

Levine, D. M., Stephan, D. F., Krehbiel, T. C., \& Berenson, M. L. (2012). Estatística: Teoria e aplicação (6a ed.). Rio de Janeiro: LTC. 
Levy, M., \& Roll, R. (2010). The market portfolio may be mean/variance efficient after all. The Review of Financial Studies, 23(6), 2464-2491.

Markowitz, H. M. (1952). Portfolio Selection. Journal of Finance, 7(1), 77-91.

Maroco, J. (2007). Análise estatística com utilização do SPSS (3a ed.). Lisboa: Edições Sílabo.

Merton, R. C. (1972). An analytic derivation of the efficient portfolio frontier. The Journal of Financial and Quantitative Analysis, 7(4), 18511872.

Oliveira, F. N., \& Paula, E. L. (2008). Determinando o grau ótimo de diversificação para investidores usuários de home brokers. Revista Brasileira de Finanças, 6(3), 437-461.

Rabelo, S. S. T. (2007). Performance das melhores práticas de governança corporativa: Um estudo de carteiras (Dissertação de Mestrado em Administração). Universidade Federal de Uberlândia, Uberlândia, Brasil.

Santiago, D. C., \& Leal, R. P. C. (2015). Carteiras igualmente ponderadas com poucas açóes e o pequeno investidor. Revista de Administração Contemporânea, 19(5), 543-563.

Santos, A. A. P., \& Tessari, C. (2012). Técnicas quantitativas de otimização de carteiras aplicadas ao mercado de açôes brasileiro. Revista de Finanças Aplicadas, 10(3), 369-394.

Sharpe, W. (1966). Mutual fund performance. The Journal of Business, 39(1), 119-138.

Sheng, H. H., \& Saito, R. (2002). Análise de métodos de replicação: $\mathrm{O}$ caso Ibovespa. Revista de Administração de Empresas - RAE, 42(2), 66-76.

Takamatsu, R. T., \& Lamounier, W. M. (2006). Anúncios de prejuízos e reaçôes dos retornos na Bovespa. Seminários em Administração, São Paulo, SP, Brasil, 9. Recuperado de http://www.semead. com.br/edicoes-anteriores- $2 /$.

Tobin, J. (1958). Liquidity preference as behavior toward risk. Review of Economic Studies, 25(1): 65-86.

Thomé, C. N., Leal, R. P. C., \& Almeida, V. S. (2011). Um índice de mínima variância de açôes brasileiras. Economia Aplicada, 15(4), 535-557.

\section{About the authors:}

1. Ricardo Goulart Serra, PhD in Business Administration (Finance) from the Faculty of Economics, Business Administration and Accounting - FEA/USP, E-mail: ricardo.serra@fecap.br

2. Wilson Toshiro Nakamura, Ph.D in Business Administration from the Faculty of Economics, Business Administration and Accounting - FEA/USP, E-mail: wtnakamura@uol.com.br

\section{Contribution of each author:}

\begin{tabular}{lcc}
\hline Contribution & Ricardo & Wilson \\
\hline 1. Definition of research problem & $\sqrt{ }$ \\
2. Development of hypotheses or research questions empirical studies) & $\sqrt{ }$ \\
3. Development of theoretical propositions (theoretical Work) & \\
4. Theoretical foundation/ Literature review & $\sqrt{ }$ \\
5. Definition of methodological procedures & $\sqrt{ }$ \\
6. Data collection & $\sqrt{ }$ \\
7. Statistical analysis & $\sqrt{ }$ \\
8. Analysis and interpretation of data & $\sqrt{ }$ \\
9. Critical revision of the manuscript & $\sqrt{ }$ \\
10. Manuscript Writing & $\sqrt{ }$ \\
11. Other (please specify which) & $\sqrt{ }$ \\
\hline
\end{tabular}


Appendix A - T portfolio composition over the 34 quarters analyzed

Portfolios 1 to 9

\begin{tabular}{|c|c|c|c|c|c|c|c|c|c|}
\hline & $\begin{array}{l}\text { Port } 1 \\
\text { Jan-03 }\end{array}$ & $\begin{array}{l}\text { Port } 2 \\
\text { May-03 }\end{array}$ & $\begin{array}{l}\text { Port } 3 \\
\text { Sept-03 } \\
\end{array}$ & $\begin{array}{l}\text { Port } 4 \\
\text { Jan-04 }\end{array}$ & $\begin{array}{l}\text { Port } 5 \\
\text { May-04 }\end{array}$ & $\begin{array}{l}\text { Port } 6 \\
\text { Sept-04 } \\
\end{array}$ & $\begin{array}{l}\text { Port } 7 \\
\text { Jan-05 }\end{array}$ & $\begin{array}{l}\text { Port } 8 \\
\text { May-05 }\end{array}$ & $\begin{array}{l}\text { Port } 9 \\
\text { Sept-05 }\end{array}$ \\
\hline ACES4 & & & & & $62.2 \%$ & $7.2 \%$ & & & \\
\hline AMBV4 & & & & & & $12.7 \%$ & $10.4 \%$ & & $56.3 \%$ \\
\hline ARCZ6 & $4.6 \%$ & $21.1 \%$ & & & & & & & $1.2 \%$ \\
\hline BBAS3 & & & & & & & $23.7 \%$ & & \\
\hline BBDC4 & & & & & & & $8.1 \%$ & $25.5 \%$ & \\
\hline BRKM5 & & & & & & & $23.3 \%$ & & \\
\hline CMET4 & & & & $18.4 \%$ & & $1.5 \%$ & & & \\
\hline CPLE6 & & & & $17.2 \%$ & & & & $49.8 \%$ & \\
\hline CRUZ3 & & & $2.1 \%$ & & & & & & \\
\hline CSNA3 & & $18.3 \%$ & $26.7 \%$ & & & & & & \\
\hline CSTB 4 & $20.1 \%$ & $2.5 \%$ & & & & & & & \\
\hline EBTP3 & & & & $10.0 \%$ & & & & & \\
\hline EBTP4 & $4.3 \%$ & & & & & & & & \\
\hline ELET3 & & & & $18.8 \%$ & & & & & \\
\hline ELPL4 & & & & $6.8 \%$ & & & & & \\
\hline EMBR 4 & & & $2.4 \%$ & $20.8 \%$ & & & & & \\
\hline GOAU4 & & & & & & $41.7 \%$ & & & \\
\hline ITSA4 & & & & & & & & & $11.2 \%$ \\
\hline ITUB 4 & & $18.6 \%$ & $25.9 \%$ & & & & & & \\
\hline PETR3 & $4.1 \%$ & & $25.8 \%$ & & & & & & $3.9 \%$ \\
\hline PETR4 & & & & & & & & & $13.9 \%$ \\
\hline PRGA4 & & & & & & & $10.0 \%$ & & \\
\hline PTIP4 & & & & & & & & & $7.9 \%$ \\
\hline SBSP3 & $7.3 \%$ & & & & & & & & \\
\hline SDIA4 & & & & & & $37.0 \%$ & & & $5.7 \%$ \\
\hline TCOC4 & $11.2 \%$ & & & & & & & & \\
\hline TMAR5 & & & & & & & $10.3 \%$ & & \\
\hline TNLP3 & & & & & & & & $24.7 \%$ & \\
\hline USIM5 & & $34.7 \%$ & $5.6 \%$ & & & & & & \\
\hline VALE3 & & & $11.3 \%$ & $4.4 \%$ & & & & & \\
\hline VALE5 & $48.4 \%$ & & & & & & $14.2 \%$ & & \\
\hline VCPA4 & & & & & $37.8 \%$ & & & & \\
\hline VIVT4 & & $4.8 \%$ & & $3.6 \%$ & & & & & \\
\hline Total & $100 \%$ & $100 \%$ & $100 \%$ & $100 \%$ & $100 \%$ & $100 \%$ & $100 \%$ & $100 \%$ & $100 \%$ \\
\hline
\end{tabular}


Portfolios 10 to 18

\begin{tabular}{|c|c|c|c|c|c|c|c|c|c|}
\hline & $\begin{array}{c}\text { Port } 10 \\
\text { Jan-06 }\end{array}$ & $\begin{array}{l}\text { Port } 11 \\
\text { May-06 }\end{array}$ & $\begin{array}{l}\text { Port } 12 \\
\text { Sept-06 }\end{array}$ & $\begin{array}{c}\text { Port } 13 \\
\text { Jan-07 }\end{array}$ & $\begin{array}{l}\text { Port } 14 \\
\text { May-07 }\end{array}$ & $\begin{array}{l}\text { Port } 15 \\
\text { Sept-07 }\end{array}$ & $\begin{array}{c}\text { Port } 16 \\
\text { Jan-08 }\end{array}$ & $\begin{array}{l}\text { Port } 17 \\
\text { May-08 }\end{array}$ & $\begin{array}{l}\text { Port } 18 \\
\text { Sept-08 }\end{array}$ \\
\hline ACES4 & & $27.9 \%$ & $26.9 \%$ & & & & & & \\
\hline ALLL11 & & & $17.4 \%$ & & & & & & \\
\hline ARCE3 & & $5.7 \%$ & & & & & & & \\
\hline BBAS3 & & & & $4.5 \%$ & & & & & \\
\hline BNCA3 & & & & & & & & & $45.4 \%$ \\
\hline BRFS3 & & $0.6 \%$ & $1.8 \%$ & & & $1.7 \%$ & & & \\
\hline BRKM5 & & & & & & $2.8 \%$ & & & \\
\hline BRTP3 & & & & & & & & $36.3 \%$ & \\
\hline CCRO3 & $20.8 \%$ & & $12.8 \%$ & $11.3 \%$ & $10.7 \%$ & & & & $41.2 \%$ \\
\hline CLSC4 & $11.4 \%$ & & $2.2 \%$ & & & & & & \\
\hline CMIG4 & & & & & & & & $4.1 \%$ & \\
\hline CPLE6 & & & & & & $2.4 \%$ & & & \\
\hline CSAN3 & & & & & & & & & $1.0 \%$ \\
\hline CSNA3 & & $30.0 \%$ & & & & $6.4 \%$ & $13.6 \%$ & & \\
\hline CYRE3 & & & & $4.5 \%$ & & & & & \\
\hline DURA4 & & & & & $24.8 \%$ & & & & \\
\hline EBTP3 & & & & & & & & & \\
\hline EBTP4 & $4.6 \%$ & & $35.9 \%$ & & & & & & \\
\hline ELET3 & & $13.8 \%$ & & & & & & & $10.0 \%$ \\
\hline ELET6 & & & & & & & & & \\
\hline ELPL4 & & & & & & $15.3 \%$ & $19.1 \%$ & & \\
\hline EMBR3 & & & & & $13.2 \%$ & & & & \\
\hline ITSA4 & $0.1 \%$ & & & & & & & & \\
\hline KLBN4 & & & & $21.9 \%$ & & & & & \\
\hline LAME4 & & & & $18.9 \%$ & & & & & \\
\hline LREN3 & & & & & & $1.5 \%$ & & & \\
\hline NATU3 & & & & & & & & $8.4 \%$ & $2.4 \%$ \\
\hline NETC4 & & & & $5.6 \%$ & & & & & \\
\hline PETR3 & & & & & & & $39.2 \%$ & & \\
\hline POSI3 & & & & & & & $4.9 \%$ & & \\
\hline PTIP4 & $13.2 \%$ & & & & $15.1 \%$ & & & & \\
\hline SBSP3 & & & & $6.5 \%$ & & & & & \\
\hline SDIA4 & & & & & $15.8 \%$ & & & & \\
\hline SUZB5 & & & & & & $22.5 \%$ & $23.3 \%$ & & \\
\hline TAMM4 & & & $3.0 \%$ & & & & & & \\
\hline TCSL4 & $42.3 \%$ & & & & & & & & \\
\hline TMAR5 & & & & & & $47.4 \%$ & & $30.3 \%$ & \\
\hline TNLP3 & $7.4 \%$ & $2.0 \%$ & & & $20.4 \%$ & & & & \\
\hline TNLP4 & $0.3 \%$ & & & & & & & & \\
\hline USIM3 & & & & & & & & $10.5 \%$ & \\
\hline USIM5 & & & & & & & & $10.4 \%$ & \\
\hline VCPA4 & & $20.1 \%$ & & $26.7 \%$ & & & & & \\
\hline Total & $100 \%$ & $100 \%$ & $100 \%$ & $100 \%$ & $100 \%$ & $100 \%$ & $100 \%$ & $100 \%$ & $100 \%$ \\
\hline
\end{tabular}


Portfolios 19 to 26

\begin{tabular}{|c|c|c|c|c|c|c|c|c|}
\hline & $\begin{array}{c}\text { Port } 19 \\
\text { Jan-09 }\end{array}$ & $\begin{array}{l}\text { Port } 20 \\
\text { May-09 }\end{array}$ & $\begin{array}{l}\text { Port } 21 \\
\text { Sept-09 }\end{array}$ & $\begin{array}{l}\text { Port } 22 \\
\text { Jan-10 }\end{array}$ & $\begin{array}{l}\text { Port } 23 \\
\text { May-10 }\end{array}$ & $\begin{array}{l}\text { Port } 24 \\
\text { Sept-10 }\end{array}$ & $\begin{array}{c}\text { Port } 25 \\
\text { Jan-11 }\end{array}$ & $\begin{array}{l}\text { Port } 26 \\
\text { May-11 }\end{array}$ \\
\hline ALLL11 & & & & $22.8 \%$ & & & & \\
\hline AMBV4 & & & $5.1 \%$ & & & & $21.4 \%$ & \\
\hline BNCA3 & $100.0 \%$ & $56.3 \%$ & & & & & & \\
\hline BRFS3 & & & $15.4 \%$ & & & & $2.2 \%$ & \\
\hline BRKM5 & & & & & & & $14.6 \%$ & $18.1 \%$ \\
\hline BTOW3 & & $1.4 \%$ & $0.6 \%$ & & & & & \\
\hline CCRO3 & & & & $3.1 \%$ & & & & \\
\hline CESP6 & & & $28.3 \%$ & & & & & \\
\hline CIEL3 & & & & & $10.3 \%$ & & & \\
\hline CMIG4 & & & $4.2 \%$ & & & & & \\
\hline CPFE3 & & & & & & $44.4 \%$ & & \\
\hline CPLE6 & & & & & & $4.3 \%$ & & \\
\hline CRUZ3 & & & $12.0 \%$ & & $36.4 \%$ & $16.3 \%$ & $17.9 \%$ & \\
\hline CSNA3 & & & & & $3.1 \%$ & & & \\
\hline ELPL4 & & $21.0 \%$ & & & & & & $0.1 \%$ \\
\hline EMBR3 & & & & & $8.6 \%$ & & & $4.5 \%$ \\
\hline GFSA3 & & & $9.3 \%$ & & & & & \\
\hline GOLL4 & & & $4.4 \%$ & & & & & \\
\hline JBSS3 & & & $7.5 \%$ & & & & & \\
\hline LREN3 & & & & & $30.6 \%$ & & & $5.5 \%$ \\
\hline MMXM3 & & $0.6 \%$ & & & $8.6 \%$ & & & \\
\hline MRFG3 & & & & & & & & $2.8 \%$ \\
\hline NETC4 & & & $6.1 \%$ & & & $1.3 \%$ & & \\
\hline OGXP3 & & $5.5 \%$ & & & & & & \\
\hline PCAR4 & & & $6.9 \%$ & $17.8 \%$ & & $17.5 \%$ & $4.2 \%$ & $5.5 \%$ \\
\hline PETR3 & & & & & & & $5.8 \%$ & \\
\hline PETR4 & & $3.2 \%$ & & & & & & \\
\hline PRML3 & & & & $20.9 \%$ & & & & \\
\hline RDCD3 & & & & & & & & $15.0 \%$ \\
\hline RSID3 & & $2.7 \%$ & $0.1 \%$ & & & $6.4 \%$ & & \\
\hline TAMM4 & & & & $5.4 \%$ & & $0.7 \%$ & & \\
\hline TCSL4 & & $9.3 \%$ & & & & $8.9 \%$ & & \\
\hline TIMP3 & & & & & & & & $3.4 \%$ \\
\hline USIM3 & & & & & & & & $22.6 \%$ \\
\hline USIM5 & & & & & $2.4 \%$ & & & \\
\hline VAGR3 & & & & & & & $4.4 \%$ & \\
\hline VALE3 & & & & $30.0 \%$ & & & & \\
\hline VIVO4 & & & & & & & $29.5 \%$ & $22.4 \%$ \\
\hline Total & $100 \%$ & $100 \%$ & $100 \%$ & $100 \%$ & $100 \%$ & $100 \%$ & $100 \%$ & $100 \%$ \\
\hline
\end{tabular}


Portfolios 27 to 34

\begin{tabular}{|c|c|c|c|c|c|c|c|c|}
\hline & \begin{tabular}{|l|} 
Port 27 \\
Sept-11 \\
\end{tabular} & $\begin{array}{l}\text { Port 28 } \\
\text { Jan-12 }\end{array}$ & \begin{tabular}{|l|} 
Port 29 \\
May-12 \\
\end{tabular} & \begin{tabular}{|l|} 
Port 30 \\
Sept-12 \\
\end{tabular} & $\begin{array}{l}\text { Port } 31 \\
\text { Jan-13 }\end{array}$ & \begin{tabular}{|l|} 
Port 32 \\
May-13 \\
\end{tabular} & $\begin{array}{l}\text { Port } 33 \\
\text { Sept-13 } \\
\end{array}$ & \begin{tabular}{|l|} 
Port 34 \\
Jan-14 \\
\end{tabular} \\
\hline ABEV3 & & & & & & & & $13.8 \%$ \\
\hline AEDU3 & & & & & & $3.0 \%$ & & \\
\hline ALLL3 & & & & & & $6.7 \%$ & & \\
\hline AMBV4 & & $32.3 \%$ & $12.6 \%$ & & $3.9 \%$ & & & \\
\hline BBAS3 & & & & & & & & $6.0 \%$ \\
\hline BBSE3 & & & & & & & $8.2 \%$ & \\
\hline BRFS3 & & & & & $8.5 \%$ & $9.5 \%$ & & \\
\hline BRKM5 & & & & & & $7.2 \%$ & & \\
\hline CCRO3 & & $0.0 \%$ & & $36.7 \%$ & $34.6 \%$ & & & \\
\hline CESP6 & & & & & & $12.4 \%$ & & $1.2 \%$ \\
\hline CIEL3 & $7.4 \%$ & $14.8 \%$ & $3.6 \%$ & $21.8 \%$ & & & & \\
\hline CMIG4 & & $4.2 \%$ & $28.0 \%$ & & & & & \\
\hline CRUZ3 & & $1.9 \%$ & $5.5 \%$ & & $3.2 \%$ & & & \\
\hline CTIP3 & & & & & & & & $3.1 \%$ \\
\hline CYRE3 & & & & & & & & \\
\hline DASA3 & & & & $6.6 \%$ & & & $5.3 \%$ & $16.0 \%$ \\
\hline DTEX3 & & & & & & $15.2 \%$ & & \\
\hline ELET6 & & & & & $0.5 \%$ & & & $11.5 \%$ \\
\hline ELPL4 & & $37.8 \%$ & & & & & & \\
\hline EMBR3 & & & $16.3 \%$ & & & & & \\
\hline ESTC3 & & & & & & & & $15.5 \%$ \\
\hline FIBR3 & & & & & $4.0 \%$ & & $26.2 \%$ & \\
\hline GFSA3 & & & & & $0.7 \%$ & & & \\
\hline GGBR4 & & & $12.2 \%$ & & & & $6.0 \%$ & \\
\hline GOLL4 & & & & & & $0.8 \%$ & & \\
\hline HGTX3 & & & $3.4 \%$ & & $5.1 \%$ & & & \\
\hline JBSS3 & & $1.2 \%$ & & & & & & \\
\hline KLBN4 & & & & & $9.0 \%$ & $19.7 \%$ & & \\
\hline KROT3 & & & & & & & $24.4 \%$ & $4.0 \%$ \\
\hline LAME4 & & & & & $11.2 \%$ & & & \\
\hline MRFG3 & & & & $6.1 \%$ & & & & \\
\hline NATU3 & & & & $28.7 \%$ & & & & \\
\hline OIBR4 & & & $0.8 \%$ & & & & & \\
\hline PCAR 4 & & & $0.9 \%$ & & & & & \\
\hline PRML3 & & & & & $1.0 \%$ & & & \\
\hline RDCD3 & $10.9 \%$ & $7.7 \%$ & $6.7 \%$ & & & & & \\
\hline SBSP3 & & & & & & & & $1.8 \%$ \\
\hline SUZB5 & & & & & & & $1.6 \%$ & \\
\hline TAMM4 & $19.3 \%$ & & & & & & & \\
\hline TIMP3 & $15.2 \%$ & & $7.9 \%$ & & & & $19.4 \%$ & \\
\hline UGPA3 & $12.9 \%$ & & $2.0 \%$ & & & $25.1 \%$ & & \\
\hline USIM3 & $1.7 \%$ & & & & & & & \\
\hline USIM5 & & & & & & & & $16.3 \%$ \\
\hline VALE3 & & & & & $14.2 \%$ & & $8.9 \%$ & \\
\hline VALE5 & & & & & $4.1 \%$ & & & $10.9 \%$ \\
\hline VIVT4 & $32.6 \%$ & & & & & $0.3 \%$ & & \\
\hline Total & $100 \%$ & $100 \%$ & $100 \%$ & $100 \%$ & $100 \%$ & $100 \%$ & $100 \%$ & $100 \%$ \\
\hline
\end{tabular}

